\title{
Irish Terrier
}

National Cancer Institute

\section{Source}

National Cancer Institute. Irish Terrier. NCI Thesaurus. Code C53719.

The Irish Terrier is a medium-sized, well-proportioned terrier with long whiskers, a bearded muzzle with powerful jaws, and bushy eyebrows. The ears are v-shaped and fold forward. The rough looking wiry outer jacket is lined with a softer undercoat. The coat is solid colored and may be red, golden, or wheaten. Height: about 18 inches $(43 \mathrm{~cm}$.) Weight: 25-27 pounds (11-12 kg.) 